
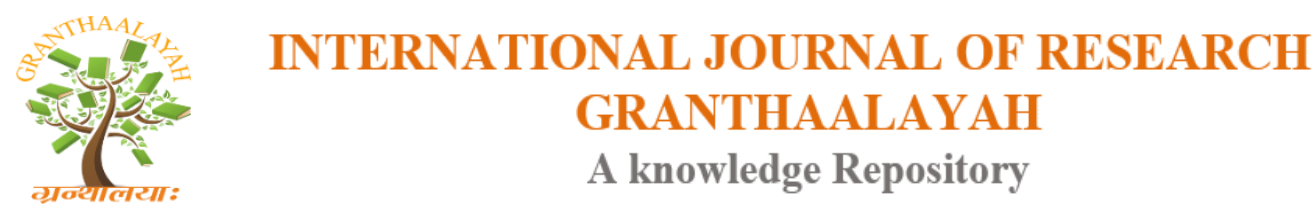

Management

\title{
DETERMINANTS OF AGRICULTURAL LOAN ACCESS FROM FORMAL SOURCES IN CROSS RIVER STATE CENTRAL AGRICULTURAL ZONE, NIGERIA
}

\author{
Ettah O. I. ${ }^{1}$, Ebu B. O. ${ }^{2}$ \\ ${ }^{1}$ Department of Agricultural Economics, Faculty of Agriculture \& Wildlife Resource \\ Management, University of Calabar, Nigeria. \\ ${ }^{2}$ Department of Agricultural Economics \& Extension, Faculty of Agriculture \& Forestry Cross \\ River University of Technology, PMB 102, Obubra, Cross River State, Nigeria
}

\begin{abstract}
Formal agricultural loan is an important tool in agricultural development and key to agricultural modernization. This is because this source of loans enables farmers to have access to production inputs as well as adopt modern farm technologies. For agricultural development to be achieved and sustained, agricultural loan is required especially in the rural areas where majority of the populace are engaged in agriculture. The study set out to analyse the determinants of agricultural loan access from formal sources in Cross River State central agricultural zone, Nigeria and proffer policy recommendations based on the findings. A three-stage random sampling technique was employed to get a total of 100 respondents with the use of a detailed structured questionnaire. Descriptive statistics and multiple regression model were used to analyse the data. Result of the analysis showed that socio-economic characteristics of farmers such as: age, gender, occupational status, household size, educational level, farming experience, farm size, farm income, off- farm income, and labour use by respondents determined farmers access or otherwise to loan from formal sources and result of the logit regression model showed that age, education, farm size, collateral, farm income and cooperative membership all affected access of loan from formal sources positively, while farm experience do not determine access of loan from formal sources. The following recommendations were made: farmers in the area should be encouraged by government to enhance their educational level, more farmland should also be made available to increase their farm size and cooperative society's membership should be encouraged by government.
\end{abstract}

Keywords: Determinants; Loan; Formal Sources; Farmers.

Cite This Article: Ettah O. I., Ebu B. O. (2018). "DETERMINANTS OF AGRICULTURAL LOAN ACCESS FROM FORMAL SOURCES IN CROSS RIVER STATE CENTRAL AGRICULTURAL ZONE, NIGERIA." International Journal of Research - Granthaalayah, 6(5), 1-8. https://doi.org/10.29121/granthaalayah.v6.i5.2018.1414. 


\section{Introduction}

Akingunola and Onayemi (2010) noted that the performance of the agricultural sector in Nigeria, as in most other developing countries is low, due largely to poor access to formal agricultural loans by farmers. In Nigeria, agriculture is not practiced in a purposeful and enterprising manner, but practiced more as a survival strategy, rather than as a business venture (Central Bank of Nigeria (CBN) (2005)). This is attributed to low-income status of farmers, because of poor access to formal loans which makes them seldom able to accumulate capital goods required for purposeful and sustainable agriculture, causing their level of capacity utilization to be Slow. According to Ettah (2010) availability of agricultural loan to farmers has been observed as one sure way of increasing agricultural output, because it would aid the improvement of efficiency and the expansion of production. It is an important tool in agricultural development and key to agricultural modernization.

Atieno (2001) posited that formal agricultural loan is money extended to farmers for agricultural purposes to enhance production and productivity as well as promote standard of living of farmers. They are the institutionalised ones characterised by rigorous processes and stringent conditions for acquisition, but with a comparative reasonable loan amount (Khorosan, 2009). According to the author their source include commercial banks, merchant banks, agricultural cooperative banks, agricultural loan and credit scheme and agricultural development banks.

Small-scale farmers who form the bulk of farmers in the area are supposedly potential beneficiaries of formal agricultural loans, but are hampered by their small peasant holdings found over wide remote areas which makes supervision by loan officers difficult (Kuye, 2016). The poor socio-economic disposition of farmers in Nigeria according to Obuo (2011) does not allow easy facilitation of agricultural loan from the formal source. This why there is a big gap between the demand for and supply of agricultural loan to farmers for agricultural activities.

The study therefore seeks to achieve the following objectives:

1) describe the socio-economic characteristics of farmers in the area,

2) describe the determinants of formal agricultural loan by farmers in the area

3) make policy recommendations

\section{Methodology}

\subsection{Sampling Procedure}

Samples for this study were collected through a three-stage random sampling technique, to ensure equitable and good spread of respondents in the study area. A total of 108 respondents were randomly selected with the use of a structured questionnaire. This instrument was subjected to a reliability test and a coefficient of 0.79 obtained, through the use of Cronbach Alpha technique, the three stages included

Selection of local government areas: From the three agricultural divisions (north, central and south) the study area is comprised of, three local government areas (LGA's) were selected randomly by the use of sampling without replacement. That is one out of each division. 
Selection of farming communities: In stage two, six farming communities were randomly selected from each of these three LGA's earlier selected. A total of eighteen farming communities made the sample.

Selection of farmers: In stage three, 11 farmers were randomly selected in each farming community made the sample of the sample. This was achieved by using the "select-and-noreplacement method". This gave a total of one hundred and ninety eight farmers, who formed the respondents.

\subsection{Data Analysis}

Objective i was realized with descriptive statistics such as mean, frequency, tables and percentages and objective (ii) by the use of logit regression model.

\subsection{Model Specification}

Multiple regression model This was used to achieve objective (ii).

The implicit form of the regression model used is specified as follows:

$\mathrm{Y}=\mathrm{f}\left(\mathrm{X}_{1}, \mathrm{X}_{2}, \mathrm{X}_{3}, \mathrm{X}_{4}, \mathrm{X}_{5}, \mathrm{X}_{6}, \mathrm{X}_{7}\right.$, e $)$

The model is specified in its explicit form as thus;

$\mathrm{Y}=\mathrm{b}_{0}+\mathrm{b}_{1} \mathrm{X}_{1}+\mathrm{b}_{2} \mathrm{X}_{2}+\mathrm{b}_{3} \mathrm{X}_{3}+\mathrm{b}_{4} \mathrm{X}_{4}+\mathrm{b}_{5} \mathrm{X}_{5}+\mathrm{b}_{6} \mathrm{X}_{6}+\mathrm{b}_{7} \mathrm{X}_{7}+\mathrm{e}$

$\mathrm{Y}_{\mathrm{i}}=$ access to formal loan source

$\mathrm{X}_{1}=$ gender (male/female)

$\mathrm{X}_{2}=$ education (no. of years in school)

$\mathrm{X}_{3}=$ age

$\mathrm{X}_{4}=$ farm size (hectare)

$\mathrm{X}_{5}=$ farm size (Naira)

$\mathrm{X}_{6}=$ collateral (property)

$\mathrm{X}_{6==}$ cooperative membership (1-yes, $0=$ no)

$\mathrm{X}_{7}=$ farming experience (no. of years in farming)

$\mathrm{e}=$ Error term

\section{Results and Discussion}

\subsection{Socio-economic Characteristics of Farmers}

Socio-economic characteristics are those attributes of farmers that influence their decisions on the use of inputs including agricultural loan in production. The socio-economic characteristics discussed in this paper included: age, gender, occupational status, household size, educational level, farming experience, farm size, farm income, off- farm income, and labour use by respondents. The results of the socio-economic characteristics in table 1 show that majority $(64.5 \%)$ of the farmers were between the ages of 31-45 years and the mean age of the farmers was 43 years. This findings imply that majority of the farmers were within the active farming age. This result was consistent with the findings of Angba and Imoke (2008) who also had the same mean age in their study. At this age, farmers are rational in decision making and application of 
appropriate inputs like loan in farm operations. Result further shows that majority (77\%) of the farmers were males, meaning that acquisition of loan from formal sources in the area could be enhanced because males in the area as in most other areas have titles to land and other assets which can be used as security for the loan as normally required by formal sources. The result is in agreement of the work of Olaitan (2006) who posited that male farmers are favoured in extension of loan than their female counterpart because they are household heads and have title to land.

Result of occupational status of farmers showed that the majority $(52 \%)$ of the farmers engaged in farming as their major occupation and $47.8 \%$ combined farming and civil service. Formal loan acquisition is hampered by these farmers because they lack the wherewithal to qualify for the loan from this source, because farmers in the area are poor with little or no capital base (Ettah, 2010). The results further showed that majority (59\%) had household size of 6-10 members, which was rather large. The study revealed that previous loans were diverted to family expenses like health care, school fees, feeding and so on, which negative affects their future loan quest from the formal source. The finding is in agreement to that of Ololade and Olagunfu (2013) who noted that low repayment rate leading to stifling of loanable funds in the area could be traceable to predominantly large family size. This hinders further access to agricultural loan from formal source. Table 4.1 further showed that majority of the farmers (44.8\%) had between 7 to 12 years of education (secondary education). This level of education may not enhance access to formal loans in the area. Studies by Enya and Alimba (2007) recommended farmers to study up to at least ordinary national diploma or it equivalent for effective comprehension of innovations in farming, especially at this computer era. The result of the farming experience of farmers shows that the majority (31.5\%) had farming experience of 21 to 30 years. Long experience in farming often make farmers stick to their traditional ways of farming (conservative), which do not encourage entrepreneurship. A total of $60 \%$ of the farmers had farm size of between 0.1 to 3 hectares; this result means that most of the farmers are small scale ones. This small sized farming could be responsible for difficulties in accessing agricultural loans from formal sources. This is because most financial institutions only give loans to medium to large scale farmers, because such farmers are perceived to break-even and even make profit to cover production cost and repay loans (Kuye, 2016).

The majority (35.8\%) received farm income of between $\$ 100,000$ - $\$ 200000$, with an average farm income of $\$ 196,000$. This could be as a result of the low rate of loan use by farmers in the area, as a result of poor access to the facility. In addition to this, most farmers $(44.8 \%)$ received annual off-farm income of $\$ 100,000$ - $\$ 500,000$. This clearly shows the reason farmers augment their incomes by getting employed in civil service and trading and pays little or no attention to loan use in agriculture. Majority (41.7\%) use only family labour, this is why majority of farmers have large family size, so that the family members could assist in farm labour. The low application of loan for farm activities in the area is also attributed to the fact that labour expenses which constitute the bulk of farm cost are avoided by farmers, this result is in agreement with the findings of (Obuo, 2011) that family labour is mostly used by rural farmers in the area.

Table 1: Socio-economic Characteristics of Farmers

\begin{tabular}{|llll|}
\hline Variable & Frequency & Percentage (\%) & Mean \\
\hline Age (years) & & & \\
\hline $15-30$ & 44 & 22.2 & $\mathbf{4 3 ( 1 9 . 0 4 3 )}$ \\
\hline $31-45$ & 128 & 64.5 &
\end{tabular}




\begin{tabular}{|c|c|c|c|}
\hline $46-60$ & 19 & 9.6 & \\
\hline 61 and above & 7 & 3.7 & \\
\hline Total & 198 & 100 & \\
\hline \multicolumn{4}{|l|}{ Gender } \\
\hline Male & 152 & 77 & \\
\hline Female & 46 & 23 & \\
\hline Total & 198 & 100 & \\
\hline \multicolumn{4}{|l|}{ Occupation } \\
\hline Farming & 103 & 52.2 & \\
\hline Civil servant & 0 & 0 & \\
\hline Trading farming and civil servant & 95 & 47.8 & \\
\hline Total & 198 & 100 & \\
\hline \multicolumn{4}{|l|}{ Household Size (number) } \\
\hline $1-5$ & 52 & 26.2 & $9(5.121)$ \\
\hline 6-10 & 117 & 59.3 & \\
\hline 11 and above & 29 & 14.5 & \\
\hline Total & 198 & 100 & \\
\hline \multicolumn{4}{|l|}{ Educational Level (years) } \\
\hline $1-6$ & 56 & 28.1 & $10(5.183)$ \\
\hline $7-12$ & 89 & 44.8 & \\
\hline $13-18$ & 38 & 19.1 & \\
\hline 18 and above & 15 & 8.0 & \\
\hline Total & 198 & 100 & \\
\hline \multicolumn{4}{|l|}{ Farming Experience (years) } \\
\hline $1-10$ & 45 & 22.8 & $9(7.013)$ \\
\hline $11-20$ & 57 & 28.7 & \\
\hline $21-30$ & 62 & 31.5 & \\
\hline 31 and above & 34 & 17.0 & \\
\hline Total & 198 & 100 & \\
\hline \multicolumn{4}{|l|}{ Farm Size (Ha) } \\
\hline $0.5-1.4$ & 53 & 26.9 & $1.8(1.145)$ \\
\hline $1.5-2.4$ & 65 & 32.7 & \\
\hline $2.5-3.4$ & 74 & 37.3 & \\
\hline 3.5 and above & 6 & 3.1 & \\
\hline Total & 198 & 100 & \\
\hline \multicolumn{4}{|l|}{ Annual farm Income (N) } \\
\hline $100000-200000$ & 70 & & $35.8 \quad 196,000$ \\
\hline $201000-300000$ & 58 & & 29.3 \\
\hline $301000-400000$ & 35 & & 17.9 \\
\hline
\end{tabular}




\begin{tabular}{|lll|}
\hline 401000 and above & 33 & 17 \\
\hline Total & $\mathbf{1 9 8}$ & $\mathbf{1 0 0}$ \\
\hline Annual Off-farm Income & & $44.8 \quad 236,000$ \\
\hline $100,000-500,000$ & 88 & 29.8 \\
\hline $501,000-1,000,000$ & 59 & 21.0 \\
\hline $1,000,001-1,500,000$ & 42 & 4.3 \\
\hline $1,500,001$ and above & 9 & $\mathbf{1 0 0}$ \\
\hline Total & $\mathbf{1 9 8}$ & \\
\hline Source of Labour & & 41.7 \\
\hline Family labour & 82 & 28 \\
\hline Hired labour & 55 & 30.3 \\
\hline Both family and hired labour & 60 & $\mathbf{1 0 0}$ \\
\hline Total & $\mathbf{1 9 8}$ &
\end{tabular}

Source: field survey, 2017

Note, figures in brackets represents standard deviation

\subsection{Access to Agricultural Loan by Farmers from Formal Sources}

Table 2 presents the maximum likelihood estimates (MLE) of the regression model described below. The estimated regression model gave an R-squared of 0.8730 for access to agricultural loan from formal sources. This indicated that the independent variables were able to explain $87 \%$ of the probability of farmers in the area accessing formal loans in the area. The coefficient of age $\left(\mathrm{X}_{1}\right)$ is positively signed and significant at 5\% level. This means that the probability of accessing formal loan increases with increase in age of farmers. The older a farmer is the more he can accumulate enough experience, collateral and confidence to access loan. This finding is in conformity with that of Kuye (2016) who reported that there is a tendency of formal loan institutions to have confidence on older farmers, because of their wealth of experience in the farm business and accumulation of farm resources that can guarantee security for the loan. The coefficient of education $\left(\mathrm{X}_{2}\right)$ is positive and significant at $10 \%$ level. This means that the probability of accessing formal loan increases with increased in the level of education of farmers. The higher the level of education of farmers the more they are aware and enlightened about agricultural loan conditions, how better to access it and also repay when the due dates arrive (Akingunola and Onayemi 2010). Farm size $\left(\mathrm{X}_{3}\right)$ is significant at $10 \%$ and positively related to access of formal loans by farmers. This implies that the probability of accessing formal loan increases with increased in farm size. This agrees with the findings of Ijioma and Osondu (2015) who posited that the larger the farm business the greater the probability of farmers breaking-even and making profit to acquire capital assets for collateral and also take care of their loan repayment obligations. Collateral $\left(\mathrm{X}_{4}\right)$ is also positively signed and significant at 5\% probability level. The implication of this result is that the probability of accessing formal loan in the area increase with increase in collateral. This result is supported by Olaitan (2006) who noted that formal loan institutions can only grant loan to farmers on the presentation of acceptable collateral and other requirements. Farm income $\left(\mathrm{X}_{5}\right)$ is significant at 5\% level which indicates that the more the income coming out of a farm the more the confidence of the formal loan lenders to extend loan to that farm and it practitioners. This result is in line 
Atieno (2001) who noted that more farm income could mean better repayment ability of that farm. Membership of cooperatives $\left(\mathrm{X}_{6}\right)$ is also positively signed and significant at 5\% probability level. The implication of this result is that the probability of accessing formal loan in the area increases with membership of cooperative societies. The finding is in agreement with that of Obuo (2011) who found out that membership of cooperatives enable farmers to pull resources together to meet conditions of formal loan requirements. Farm exp. $\left(\mathrm{X}_{7}\right)$ is not significant to determine access of agricultural loan from formal source.

Table 2: Determinants of Access to Loan from formal sources by Farmers

\begin{tabular}{|c|c|c|c|c|c|}
\hline Variables & Coefficient & Std error & $\mathbf{Z}$ & slope & p-values \\
\hline Const. & -42.0794 & 19.5877 & -2.1483 & - & $0.03169 * *$ \\
\hline$\left(\mathrm{X}_{1}\right)$ & 2.01625 & 0.985366 & 2.0462 & 0.095089 & $0.04074 * *$ \\
\hline Educ. & 0.0300241 & 0.66666 & 1.8015 & 0.014598 & $0.07163 * * *$ \\
\hline Farm size & 1.40622 & 5.81065 & 2.4201 & 6.63192 & $0.01552 * * *$ \\
\hline Collateral & 28.2041 & 141397 & 1.9947 & 0.999975 & $0.04608 * *$ \\
\hline Farm income $\left(\mathrm{X}_{5}\right)$ & 9.52536 & 5.24637 & 0.1816 & 4.49228 & $0.85593 * *$ \\
\hline Co-op memb. $\left(\mathrm{X}_{6}\right)$ & 0.0998601 & 0.0864967 & 1.1545 & 0.00470953 & $0.24830 * * *$ \\
\hline Farm exp. & -4.53119 & 9.1397 & 0.4958 & 2.13697 & $0.62008 *$ \\
\hline R-squared & 0.872993 & \multicolumn{3}{|c|}{ Adjusted R-squared 0.730083} & \\
\hline Log-likelihood & -7.998521 & Akaike criterion & 33.99 & 9704 & \\
\hline
\end{tabular}

Likelihood ratio test: Chi- squared $(7)=98.4922$

Source: estimated from field survey data, 2017

$*, * *, * * *$ statistical significance at 5 and 10 percent levels respectively

\section{Conclusion and Recommendations}

Accessibility of formal agricultural loan by farmers has been observed as one sure way of increasing agricultural output, through the improvement of efficiency and the expansion of production. The study was designed to describe the socio-economic characteristics of farmers and determine access to formal agricultural loan by farmers as well as proffer recommendations based on the findings.

Socio-economic characteristics of farmers such as: age, gender, occupational status, household size, educational level, farming experience, farm size, farm income, off- farm income, and labour use by respondents determined farmers access to loan from formal sources and result of regression analysis showed that age, education, farm size, collateral, farm income and cooperative membership all affected access of loan from formal sources positively, while farm experience do not determine access of loan from formal sources. The following recommendations are made: farmers in the area should be encouraged by government to enhance their educational level, more farmland should also be made available to increase their farm size and cooperative society's membership should be encouraged by government. 


\section{References}

[1] Akingunola, R. O. \& Onayemi S.O. (2010). The role of informal finance in the development of women micro - business in Nigeria, A case study of Ogun and Oyo States. International. Journal of Academic Research. 2 (5):121-130.

[2] Angba, A. O \& Imoke, G. (2008). Effects of of credit use on the gross margin of rice enterprise in Abi Local Government Area of Cross River State. Journal of Agriculture, Forestry and Social Sciences.

[3] Atieno, R. (2001) Formal and informal institutions lending policies and access to credit by small scale enterprise in Kenya: An empirical assessment by AERC (African Economics Research Consortium) research paper 111 Nairobi November.

[4] Central Bank of Nigeria (2005). Microfinance policy, Regulatory and supervisory frame work for Nigeria. Publication Guidelines Microfinance Policy in Nigeria. Central bank of Nigeria. Abuja December 2005.

[5] Enya, V. E \& Alimba, J. (2007) Analysis of factors affecting demand for agriculture credit from commercial banks. Journal of Agriculture for Social Science. 5 (1): 52-57.

[6] Ettah, O.I (2010) Effects of credit acquisition and repayment on agricultural production in Cross River State, Nigeria. M. Sc thesis submitted to the Department of Agricultural Economics University of Nsukka. Retrieved from repository.unn.edu.ng on the 12/12/2015.

[7] Ijioma, J. C. \& Osondu, C. K. (2015) Agricultural credit sources and determinants of credit acquisition by farmers in Idemili Local Government Area of Anambra State. Journal of Agricultural Science and Technology B5:34-43.

[8] Khorosan, R. (2009). Farmers' access to micro credit. Paper presented at the Conference on International Research on Food Security, Natural Resource Management and Rural Development. University of Hamburg. Oct 6-8, 2009.

[9] Kuye, O. O. (2016). Determinants of Loan Default and Repayment Rates by Cassava

[10] Farmers in South-South Nigeria: A Case Study of Bank of Agriculture and First

[11] Bank of Nigeria. European Journal of Agriculture and Forestry Research Vol.3,

[12] No.4, pp.48-57, September, (www.eajournals.org).

[13] Obuo, P. O. (2011). Comparative analysis of the operations of formal and informal credit sources

[14] in Nigeria: the case of NACRDB and BAM in Northern Agricultural zone of Cross River

[15] State. Unpublished M.Sc thesis in the Department of Agricultural Economics and

[16] Extension, University of Calabar, Calabar.

[17] Olaitan, A. S. (2006). Formal - informal institutional linkages in the Nigerian agricbusiness sector and implication for pro-poor growth. IPPG discussion paper series 37. NISER Ibadan.

[18] Ololade, R. A. \& Olagunfu, F. I.(2013) Determinants of access to credit among rural farmers in Oyo State, Nigeria. Global Journal of Science Frontier Research, Agriculture and Veterinary Science 13(1) : 17-23.

*Corresponding author.

E-mail address: ettahotu@g mail.com 